$\xi=-1$

\title{
Development of Android-based Rabbit Disease Expert System
}

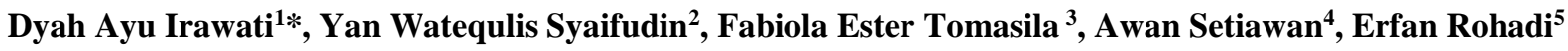 \\ 1,2,3,4,5 State Polytechnic of Malang \\ *Corresponding author E-mail: dyah.ayu@ polinema.ac.id,
}

\begin{abstract}
Many rabbit keepers or breeders are panics when their rabbit has an illness. This paper proposed an expert diagnostic system application for Android-based rabbit disease using the Naïve Bayes method to determine the illness and Certainty Factor for the trust value of the condition by combining the rate of the trust of users and experts due to diagnose the diseases of the rabbit.

The testing was using 65 data learning and 160 data learning to test the naïve Bayes method. Furthermore, the certainty factor is using $\mathrm{CF}$ user 1 and its variation.

The results obtained for 65 data learning is $53 \%$, while 160 data learning is $73 \%$. With the naïve Bayes method, it can be concluded that the more data learning, the better and more accurate the system. The results of conformity with the testing data obtained from the variative CF user value, namely 53\% accordingly, $13 \%$ inappropriate, $33 \%$ near. The effect of compliance with the sample data collected from the $\mathrm{CF}$ value of user 1 is $53 \%$ appropriate, $7 \%$ inappropriate, $40 \%$ is near. With the certainty factor method, it can be concluded that differences in user input values affect the overall $\mathrm{CF}$ value.

Keywords: expert system, naïve bayes, certainty factor, rabbit disease.
\end{abstract}

\section{Introduction}

Rabbits are mammals from the family of Leporidae, which can be found in many parts of the earth. Today many people cultivate rabbits as pets. Often rabbits are attacked by diseases due to various good factors due to the condition of the cage and food. In this case, many rabbit keepers or farmers panicked when their rabbit was stricken with the disease. It is necessary to create an expert media that can be accessed by rabbit owners who are online as an application which helps to identify rabbits disease and provide first aid to rabbits.

Along with the development of modern science and technology, especially in the field of information technology which is so rapid, computer technology can be used to help humans in various kinds of work, such as health diagnosis. Applications that applied for this need are applications related to intelligent systems, which is an expert system. Before transfer the expertise to the system, it must be known in advance how the expert works. In this paper, experts are veterinarians in an animal clinic. The veterinarian will diagnose the disease suffered based on the symptoms that appear from the rabbit. From the conclusion of the disease, new solutions were given to treat the disease. This expert system is expected to help the rabbit owner get information about the diagnosis of the disease and how to deal with the disease based on the symptoms that appear. An expert or veterinarian will list the symptoms experienced by the animal, and from the list of symptoms can be made a diagnosis process. The disease in rabbits generally has symptoms that are almost the same between one type and the other, so that the signs of $\mathrm{X}$ are not necessarily just the symptoms that cause type A disease. Symptoms of X may also cause type B disease and others. With these problems, it is necessary to build an expert system application for diagnosing rabbit disease. Previous research has made this system web-based.
Based on a survey from We Are Social, a social marketing agen$\mathrm{cy}$, issued a report on the data on the number of mobile users from around the world, and Indonesia is one of the countries who has the largest mobile user in the world[3][9]. The system will be developed into the Android platform. Development of Androidbased Rabbit Diagnosis Expert System uses two methods, Naïve Bayes and Certainty Factor. The Naive Bayes method is for the classification process, in the system process requires training data and test data, while the Certainty Factor method is used to deal with problems whose answers are uncertain.

The research objective of the Development of Android-based Rabbit Diagnosis Expert System is to make a rabbit disease classification system using the Naive Bayes method to determine the disease - a certainty factor method to determine the value of trust and test an expert system for diagnosis of rabbit disease and help the first treatment of rabbits.

\section{Literature Review}

This section discuss about Naïve Bayes, Certainty Factor and related previous study

\subsection{Previous Research}

Previous research related with expert system are done by some research[1][2][5]. The studies in [1] show that this expert system can help people recognize various symptoms, types of diseases and solutions for how to treat rabbits. For further research can be further developed into android-based applications. The studies based on Forward Chaining method.

Studies in [2] show that the expert system that is built can recognize and know the disease in rabbits using the certainty factor $(\mathrm{CF})$ method and produce solutions to help treat diseases. For future development, it can make a better presentation of symptoms data 
choices to make it easier to use this expert system and can be developed in the latest platform.

And studies in [5] show that the Naïve Bayes expert system of respiratory disorders in children has been able to provide information to the use of the types of respiratory diseases based on the symptoms given. For the subsequent development of the knowledge base to always be updated by the development of science and technology.

\subsection{Naïve Bayes}

According to Olson and Delen explained Naïve Bayes for each class of decisions, calculating the probability with the condition that the decision class is correct, considering the vector of object information. This algorithm assumes that object attributes are independent. The probability involved in producing the final estimate is calculated as the number of frequencies of the "master" decision table.

Bayes calculation can be done using the following steps:

1. Find the prior value for each class by calculating the average of each class using the equation.

$$
P=\frac{X}{A}
$$

2. Look for likelihood values for each class using the equation

$$
L=\frac{F}{B}
$$

3. Look for the posterior value of each class that exists using the equation

$$
P(H \mid E)=P(H) \times P(E \mid H)
$$

Class classification results using the Naive Bayes method are done by comparing the posterior values of the existing classes. The highest posterior value selected as a result of classification.

Naive Bayes in expert systems has a role as an inference engine. Where the diagnosis process is determined by the input of symptoms by the user, then each symptoms entered is processed by calculating the classification of naive Bayes. Diagnosis results are taken from the maximum value of the disease sought based on the knowledge base.

\subsection{Certainty Factor}

According to Turban, Certainty Factor is a method used to express trust in an event (facts or hypothesis) based on evidence or expert judgment [8]. Certainty Factor (CF) can occur with a variety of conditions. Among the states that arise is that there are several antecedents (in different rules) with the same consequence.

$$
\mathrm{CF}(\mathrm{H}, \mathrm{E})=\mathrm{MB}(\mathrm{H}, \mathrm{E})-\mathrm{MD}(\mathrm{H}, \mathrm{E})
$$

Explanation :

a. $\mathrm{CF}(\mathrm{H}, \mathrm{E})=$ Certainty Factor of the $\mathrm{H}$ hypothesis which is influenced by the evidence $\mathrm{E}$. The amount of $\mathrm{CF}$ ranges from -1 to 1 . The value of 1 indicates absolute trust while the value of -1 indicates absolute distrust

b. $\mathrm{MB}(\mathrm{H}, \mathrm{E})=$ measure of increase in confidence (measure of increased belief) to the hypothesis $\mathrm{H}$ which is affected by symptoms of $\mathrm{E}$

c. $\mathrm{MD}(\mathrm{H}, \mathrm{E})=$ measure of increase in distrust (measure of increased disbelief) against hypothesis $\mathrm{H}$ which is affected by symptoms of $\mathrm{E}$

The CF value (Rule) is obtained from the interpretation of "term" from the expert, which is converted into a specific $\mathrm{CF}$ value. There are 2 values of certainty factor, namely:
- $\quad$ The value of certainty factor rules whose values are attached to a certain rule and the value given by the expert.

- The value of the certainty factor provided by the user to represent the degree of certainty/confidence in the premise (e.g., symptoms, conditions, characteristics) experienced by the user.

\subsection{System Overview}

Android-based Rabbit Disease Expert System is an application which will help the rabbit keepers or breeders in diagnosing the illness of their rabbit by the visible symptoms.

The knowledge representation in this application based on the interviewed veterinarian.

Data collection did by interviewing veterinarian. Observations were carried out at the House of Malang pets, with Hadirotus Okvianty Mustika P. as the veterinarian.

\section{Implementation}

This research uses the Expert Methodology System Development Life Cycle. The development model uses stages that represent the needs of expert systems for diagnosing rabbits diseases using the Naïve Bayes method and Certainty Factor. The steps of the activities are:

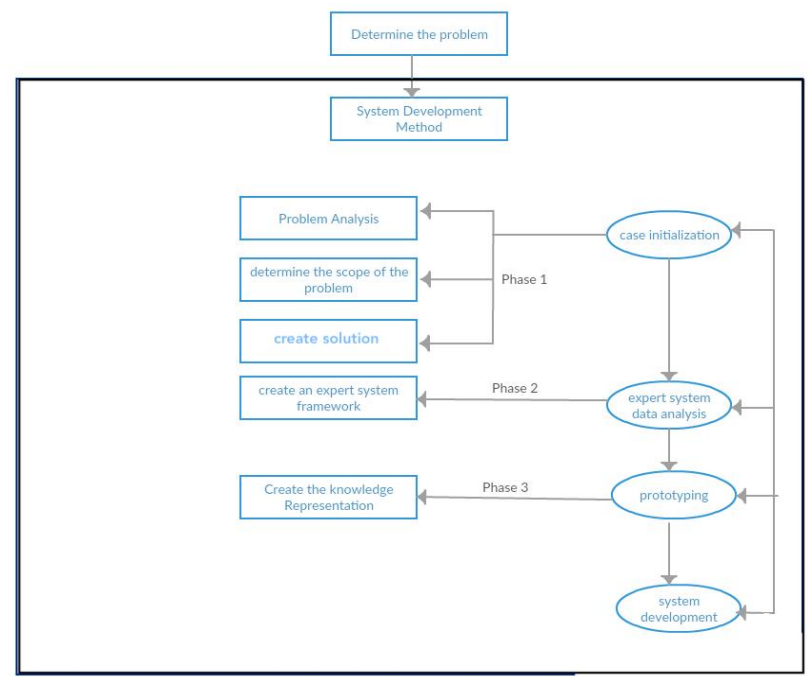

fig. 1 Framework of Thinking

The steps of the expert methodology system development life cycle are :

\subsection{Initialization}

At this stage, the problem is determined by the diagnosis of disease in rabbits. The observation data is reviewed then define the problem scope. The acquisition of knowledge of disease symptoms is intended to assess the mindset of the system.

\subsection{Expert System Data Analysis}

In this stage is to determine the Naive Bayes method for the classification process. The system process requires training data and test data, then the Certainty Factor used as a technique used to overcome uncertainty in decision making and show the amount of trust.

\subsection{Basic Case Prototype}

At this stage knowledge representation is carried out. Knowledge obtained from experts represented in a format that is understood by humans and can be executed by computers. 


\subsection{System Design}

After the information needed has been represented, then the next step is making a design system. The designs are

a. Use Case

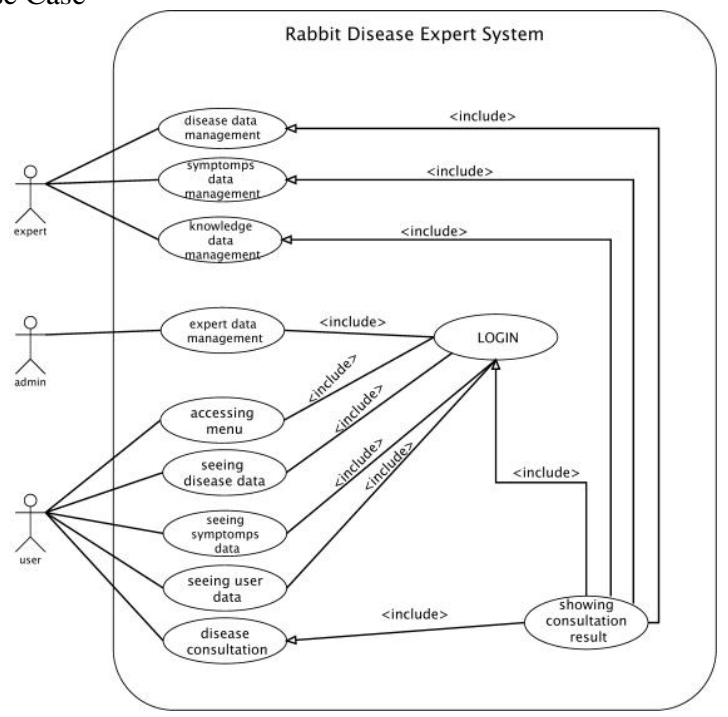

fig 2. Use case diagram

From the use case diagram, this system has 3 users i.e expert, admin and user. Expert manages disease data, symptom data, and knowledge data, while users can consult and produce consultation results in expert knowledge data, then admin manages expert data.

b. Flowchart

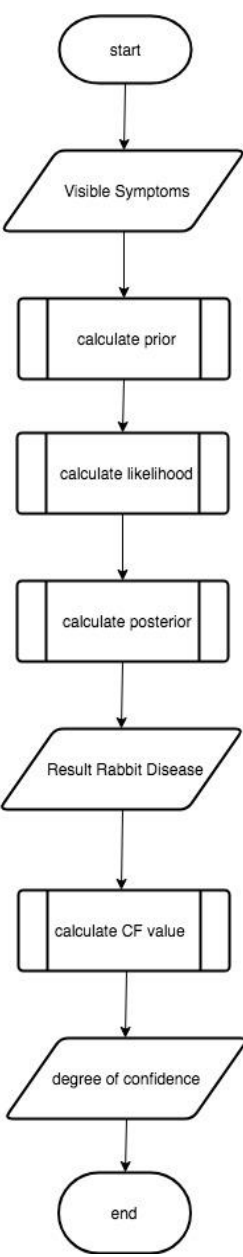

fig 3. Flowchart
The algorithmic flow of the Naive Bayes method determines the type of disease by calculating prior values, likelihood values, and posterior values then produce the result of the disease, then Certainty Factor determines the degree of trust by combining expert and user trust values which can be seen in Figure 3.

\subsection{System Development}

The following is a little excerpt from the observations at the House Of Pets Malang in the form of a medical record list. In the table 2.1 there is list for the kind of disease.

Table 2.1 The Disease

\begin{tabular}{|c|l|}
\hline \multicolumn{2}{|c|}{ List of Disease } \\
\hline Code & \multicolumn{1}{c|}{ Name } \\
\hline P1 & scabies \\
\hline P2 & malocclusion \\
\hline P3 & earmites \\
\hline P4 & furmites \\
\hline P5 & dhiarrea \\
\hline P6 & flu \\
\hline P7 & wormy \\
\hline P8 & coccidiosis \\
\hline P9 & eye inflammation \\
\hline P10 & hairball \\
\hline
\end{tabular}

In the table 2.2 is the list of the symptoms and their codes.

Table 2.2 List of Symptoms

\begin{tabular}{|c|c|c|c|}
\hline \multicolumn{4}{|c|}{ List Of Symptoms } \\
\hline Code & Name of Symptoms & Code & Name of Symptoms \\
\hline G1 & there is scab / crust & G19 & Watery eyes \\
\hline G2 & $\begin{array}{l}\text { scratching in certain } \\
\text { parts of its body }\end{array}$ & G20 & The eyes look red \\
\hline \multirow{2}{*}{ G3 } & Hair loss/alopecia & G21 & $\begin{array}{c}\text { There are traces of dirt in } \\
\text { the eyes }\end{array}$ \\
\hline G4 & dirty ear section & G22 & Empty stomach \\
\hline G5 & pain on the ear & G23 & Rocking teeth \\
\hline G6 & reddish & G24 & Body temperature rises \\
\hline G7 & fleas & G25 & Erratic body temperature \\
\hline G8 & mushy feces & G26 & Slimy feces \\
\hline G9 & weak & G27 & Bloody dirt \\
\hline G10 & blown & G28 & Dull fur \\
\hline G11 & Runny nose & G29 & The anus is dirty \\
\hline G12 & sneezing & G30 & Fever \\
\hline G13 & elongated teeth & G31 & Do not want to eat \\
\hline G14 & swollen gums & G32 & Little appetite \\
\hline & $\begin{array}{l}\text { bloated / enlarged } \\
\text { stomach }\end{array}$ & G33 & Appetite goes down \\
\hline G15 & Stress & G34 & Itchy \\
\hline G16 & Weight loss & G35 & The face looks pale \\
\hline G17 & Thin body & G36 & Scratching the body \\
\cline { 2 - 4 } G18 & G37 & There is fur in the feces \\
\hline & & & \\
\hline
\end{tabular}

In table 2.3 is a list of medical records of some rabbits and what symptoms they experience and their disease.

Table 2.3 some sample data of the medical records in the clinic

\begin{tabular}{|l|l|l|l|}
\hline No & $\begin{array}{c}\text { Rabbit } \\
\text { Name }\end{array}$ & \multicolumn{1}{|c|}{ Symptoms } & \multicolumn{1}{|c|}{$\begin{array}{c}\text { Disease } \\
\text { Name }\end{array}$} \\
\hline 1 & CIMO & $\begin{array}{l}\text { thin scabs on the ears and fingers, } \\
\text { scratching the scabs part. }\end{array}$ & Scabies \\
\hline 2 & NN & $\begin{array}{l}\text { long section right incisors, rocking } \\
\text { teeth. (can cut only the lower teeth), } \\
\text { it wants to eat a little amount }\end{array}$ & malocclusion \\
\hline 3 & Enci & there is crust, itching, hair loss & Scabies \\
\hline 4 & NN & $\begin{array}{l}\text { dirty ears, it always scratches the } \\
\text { ears, if ears held then the rabbit } \\
\text { feels pain }\end{array}$ & Earmites \\
\hline 5 & Linlin & $\begin{array}{l}\text { thick crust, crust on the eyelids \& } \\
\text { nose }\end{array}$ & Scabies \\
\hline 6 & NN & $\begin{array}{l}\text { hair loss + redness on the four legs } \\
\text { starts to bite up to the top. back } \\
\text { crust. reddish nose. dental norm }\end{array}$ & Scabies \\
\hline 7 & Yessie & $\begin{array}{l}\text { hair loss, there are active fleas } \\
\text { (some move in rabbit hair) }\end{array}$ & Furmites \\
\hline
\end{tabular}




\begin{tabular}{|l|l|l|l|}
\hline 8 & Sandra & $\begin{array}{l}\text { mushy dirt, lack of appetite, lethar- } \\
\text { gy }\end{array}$ & diarrhea \\
\hline 9 & Moly & there is crust / dandruff in the foot & Scabies \\
\hline 10 & Gendut & there is a severe crust & Scabies \\
\hline 11 & Popi & $\begin{array}{l}\text { There is a crust on the ears and feet, } \\
\text { alopexia. Eat normal }\end{array}$ & Scabies \\
\hline 12 & Xingxing & $\begin{array}{l}\text { The incisors are elongated, appetite } \\
\text { decreases. }\end{array}$ & Maloklusi \\
\hline 13 & Monyo & $\begin{array}{l}\text { Anorexia, runny nose, weakness, } \\
\text { decreased appetite, mushy feces }\end{array}$ & Flu \\
\hline 14 & Cifewy & $\begin{array}{l}\text { Temperature up and down, last meal } \\
\text { in the morning, mushy dirt (smelly, } \\
\text { green) bloated, lethargic, dirty part } \\
\text { of the anus }\end{array}$ & diarrhea \\
\hline
\end{tabular}

There are 65 examination datas from medical record in the clinic, tabel 2.4 shows the summary of the examination data.

Table 2.4 Sum of The Disease

\begin{tabular}{|c|l|}
\hline Disease & Total \\
\hline scabies & 33 \\
\hline malocclusion & 11 \\
\hline earmites & 1 \\
\hline furmites & 3 \\
\hline dhiarrea & 11 \\
\hline flu & 2 \\
\hline wormy & 1 \\
\hline coccidiosis & 1 \\
\hline eye inflammation & 1 \\
\hline hairball & 1 \\
\hline
\end{tabular}

With Naïve Bayes classification, the result of each step will be shown in the table 2.5 until 2.8 .

Table 2.5 shows the result of normalization. Normalization is sum of the total amount of each disease with total amount of symptoms

Table 2.5 Normalization

\begin{tabular}{|c|c|c|}
\hline Disease & Total & Normalization \\
\hline scabies & 33 & 70 \\
\hline malocclusion & 11 & 48 \\
\hline earmites & 1 & 38 \\
\hline furmites & 3 & 40 \\
\hline dhiarrea & 11 & 48 \\
\hline flu & 2 & 39 \\
\hline wormy & 1 & 38 \\
\hline coccidiosis & 1 & 38 \\
\hline eye inflammation & 1 & 38 \\
\hline hairball & 1 & 38 \\
\hline
\end{tabular}

Table 2.6 shows the prior value of each disease.

Table 2.6 Prior Value

\begin{tabular}{|c|c|c|c|}
\hline \multicolumn{5}{|c}{ Table 2.6 Prior Value } \\
\hline Disease & Total & Normalization & Prior \\
\hline scabies & 33 & 70 & 1,0769 \\
\hline malocclusion & 11 & 48 & 0,7385 \\
\hline earmites & 1 & 38 & 0,5846 \\
\hline furmites & 3 & 40 & 0,6154 \\
\hline dhiarrea & 11 & 48 & 0,7385 \\
\hline flu & 2 & 39 & 0,6000 \\
\hline wormy & 1 & 38 & 0,5846 \\
\hline coccidiosis & 1 & 38 & 0,5846 \\
\hline eye inflammation & 1 & 38 & 0,5846 \\
\hline hairball & 1 & 38 & 0,5846 \\
\hline
\end{tabular}

New input data will be used to count the likelihood value. Tabel 2.7 shows the new input data and its trust value.

Table 2.7 New Input Data

\begin{tabular}{|c|c|}
\hline Symptoms input & Trust Value for CF \\
\hline G8 & 0,6 \\
\hline G9 & 0,8 \\
\hline G24 & 0,6 \\
\hline G36 & 0,4 \\
\hline
\end{tabular}

Table 2.8 is the result of posterior value after each likelihood for each symptom of each disease was multiplied. The highest posterior value is the disease based on Naïve Bayes calculation. So, for the new data input in Table 2.7 the disease will be wormy. And trust value in table 2.7 is used for calculation in Certainty Factor to see if the result is suitable with the trust value from the experts.

Table 2.8 Posterior Value

\begin{tabular}{|c|c|c|c|}
\hline Disease & Prior & Likelihood & Posterior \\
\hline scabies & 1,0769 & 0,06 & 0,06 \\
\hline malocclusion & 0,7385 & 0,26 & 0,19 \\
\hline earmites & 0,5846 & 0,83 & 0,49 \\
\hline furmites & 0,6154 & 0,66 & 0,41 \\
\hline dhiarrea & 0,7385 & 0,38 & 0,28 \\
\hline flu & 0,6000 & 0,77 & 0,46 \\
\hline wormy & 0,5846 & 0,88 & 0,51 \\
\hline coccidiosis & 0,5846 & 0,83 & 0,49 \\
\hline eye inflammation & 0,5846 & 0,81 & 0,47 \\
\hline hairball & 0,5846 & 0,83 & 0,49 \\
\hline
\end{tabular}

The results of observations at Malang House of Pets in the form of a list of CF values or belief values per symptom in each disease according to experts is in table 2.9

Table 2.8 Trust Value

\begin{tabular}{|c|c|c|c|c|c|c|c|c|c|c|}
\hline \multirow{2}{*}{$\begin{array}{c}\text { Symp- } \\
\text { toms } \\
\text { Code }\end{array}$} & \multicolumn{10}{|c|}{ Trust Value from experts per disease } \\
\hline & P1 & $\mathbf{P 2}$ & P3 & P4 & P5 & P6 & P7 & P8 & P9 & $\begin{array}{c}\text { P1 } \\
\text { 0 }\end{array}$ \\
\hline G1 & $\begin{array}{r}0 . \\
6 \\
\end{array}$ & & $\begin{array}{r}0 . \\
4 \\
\end{array}$ & & & & & & & \\
\hline G2 & $\begin{array}{r}0 . \\
6\end{array}$ & & $\begin{array}{r}0 . \\
8\end{array}$ & $\begin{array}{r}0 . \\
8\end{array}$ & & & & & & \\
\hline G3 & $\begin{array}{r}0 . \\
6 \\
\end{array}$ & & $\begin{array}{r}0 . \\
4 \\
\end{array}$ & $\begin{array}{r}0 . \\
6 \\
\end{array}$ & $\begin{array}{r}0 . \\
4\end{array}$ & $\begin{array}{r}0 . \\
4 \\
\end{array}$ & $\begin{array}{r}0 . \\
4 \\
\end{array}$ & $\begin{array}{r}0 . \\
4 \\
\end{array}$ & $\begin{array}{r}0 . \\
4 \\
\end{array}$ & 0.6 \\
\hline G4 & $\begin{array}{r}0 . \\
4\end{array}$ & & $\begin{array}{r}0 . \\
6 \\
\end{array}$ & $\begin{array}{r}0 . \\
4 \\
\end{array}$ & & & & & & \\
\hline G5 & $\begin{array}{r}0 . \\
4\end{array}$ & & $\begin{array}{r}0 . \\
6 \\
\end{array}$ & & & & & & & \\
\hline G6 & $\begin{array}{r}0 . \\
6 \\
\end{array}$ & & $\begin{array}{r}0 . \\
6 \\
\end{array}$ & $\begin{array}{r}0 . \\
4 \\
\end{array}$ & & $\begin{array}{r}0 . \\
4 \\
\end{array}$ & & & $\begin{array}{r}0 . \\
4 \\
\end{array}$ & 0.6 \\
\hline G7 & & & $\begin{array}{r}0 . \\
4 \\
\end{array}$ & $\begin{array}{r}0 . \\
4 \\
\end{array}$ & & & & & & \\
\hline G8 & & $\begin{array}{r}0 . \\
4\end{array}$ & & & $\begin{array}{r}0 . \\
4\end{array}$ & $\begin{array}{r}0 . \\
4\end{array}$ & $\begin{array}{r}0 . \\
6 \\
\end{array}$ & $\begin{array}{r}0 . \\
6 \\
\end{array}$ & $\begin{array}{r}0 . \\
4 \\
\end{array}$ & 0.4 \\
\hline G9 & $\begin{array}{r}0 . \\
4\end{array}$ & $\begin{array}{r}0 . \\
4 \\
\end{array}$ & $\begin{array}{r}0 . \\
4 \\
\end{array}$ & $\begin{array}{r}0 . \\
4 \\
\end{array}$ & $\begin{array}{r}0 . \\
4\end{array}$ & $\begin{array}{r}0 . \\
4 \\
\end{array}$ & $\begin{array}{r}0 . \\
4 \\
\end{array}$ & $\begin{array}{r}0 . \\
4 \\
\end{array}$ & $\begin{array}{r}0 . \\
4 \\
\end{array}$ & 0.4 \\
\hline G10 & & & & & & $\begin{array}{r}0 . \\
4 \\
\end{array}$ & $\begin{array}{r}0 . \\
4 \\
\end{array}$ & $\begin{array}{r}0 . \\
4 \\
\end{array}$ & & 0.4 \\
\hline G11 & & & & & & $\begin{array}{r}0 . \\
6 \\
\end{array}$ & $\begin{array}{r}0 . \\
4 \\
\end{array}$ & $\begin{array}{r}0 . \\
4\end{array}$ & $\begin{array}{r}0 . \\
4\end{array}$ & \\
\hline G12 & & & & $\begin{array}{r}0 . \\
4\end{array}$ & & $\begin{array}{r}0 . \\
6 \\
\end{array}$ & & & $\begin{array}{r}0 . \\
4\end{array}$ & \\
\hline G13 & & $\begin{array}{r}0 . \\
8\end{array}$ & & & $\begin{array}{r}0 . \\
4\end{array}$ & $\begin{array}{r}0 . \\
4 \\
\end{array}$ & $\begin{array}{r}0 . \\
4 \\
\end{array}$ & $\begin{array}{r}0 . \\
4\end{array}$ & $\begin{array}{r}0 . \\
4\end{array}$ & 0.4 \\
\hline G14 & & $\begin{array}{r}0 . \\
6 \\
\end{array}$ & & & & $\begin{array}{r}0 . \\
4 \\
\end{array}$ & & $\begin{array}{r}0 . \\
4 \\
\end{array}$ & & \\
\hline G15 & & $\begin{array}{r}0 . \\
4\end{array}$ & & & $\begin{array}{r}0 . \\
4\end{array}$ & $\begin{array}{r}0 . \\
4\end{array}$ & $\begin{array}{r}0 . \\
4\end{array}$ & $\begin{array}{r}0 . \\
4\end{array}$ & $\begin{array}{r}0 . \\
4 \\
\end{array}$ & 0.4 \\
\hline G16 & $\begin{array}{r}0 . \\
4\end{array}$ & $\begin{array}{r}0 . \\
4\end{array}$ & $\begin{array}{r}0 . \\
4\end{array}$ & $\begin{array}{r}0 . \\
4\end{array}$ & $\begin{array}{r}0 . \\
4\end{array}$ & $\begin{array}{r}0 . \\
4\end{array}$ & $\begin{array}{r}0 . \\
4\end{array}$ & $\begin{array}{r}0 . \\
4\end{array}$ & $\begin{array}{r}0 . \\
4\end{array}$ & 0.4 \\
\hline G17 & $\begin{array}{r}0 . \\
4\end{array}$ & $\begin{array}{r}0 . \\
4 \\
\end{array}$ & $\begin{array}{r}0 . \\
4\end{array}$ & $\begin{array}{r}0 . \\
4 \\
\end{array}$ & $\begin{array}{r}0 . \\
4\end{array}$ & $\begin{array}{r}0 . \\
4 \\
\end{array}$ & $\begin{array}{r}0 . \\
4\end{array}$ & $\begin{array}{r}0 . \\
6 \\
\end{array}$ & $\begin{array}{r}0 . \\
4\end{array}$ & 0.4 \\
\hline G18 & $\begin{array}{r}0 . \\
4\end{array}$ & $\begin{array}{r}0 . \\
4 \\
\end{array}$ & $\begin{array}{r}0 . \\
4 \\
\end{array}$ & $\begin{array}{r}0 . \\
4 \\
\end{array}$ & $\begin{array}{r}0 . \\
4\end{array}$ & $\begin{array}{r}0 . \\
4 \\
\end{array}$ & $\begin{array}{r}0 . \\
4\end{array}$ & $\begin{array}{r}0 . \\
6 \\
\end{array}$ & $\begin{array}{r}0 . \\
4 \\
\end{array}$ & 0.4 \\
\hline G19 & 0 & $\begin{array}{c}0 . \\
4 \\
\end{array}$ & 0 & 0 & $\begin{array}{c}0 . \\
4\end{array}$ & $\begin{array}{c}0 . \\
4\end{array}$ & $\begin{array}{c}0 . \\
4\end{array}$ & $\begin{array}{c}0 . \\
4\end{array}$ & $\begin{array}{c}0 . \\
4\end{array}$ & \\
\hline $\mathrm{G} 20$ & & $\begin{array}{r}0 . \\
4\end{array}$ & & & $\begin{array}{r}0 . \\
4\end{array}$ & $\begin{array}{r}0 . \\
4 \\
\end{array}$ & $\begin{array}{r}0 . \\
4\end{array}$ & $\begin{array}{r}0 . \\
4 \\
\end{array}$ & $\begin{array}{r}0 . \\
6 \\
\end{array}$ & \\
\hline G21 & & & & & & $\begin{array}{r}0 . \\
4 \\
\end{array}$ & & & $\begin{array}{r}0 . \\
6 \\
\end{array}$ & \\
\hline $\mathrm{G} 22$ & $\begin{array}{r}0 . \\
4\end{array}$ & $\begin{array}{r}0 . \\
4 \\
\end{array}$ & $\begin{array}{r}0 . \\
4 \\
\end{array}$ & $\begin{array}{r}0 . \\
4 \\
\end{array}$ & $\begin{array}{r}0 . \\
4\end{array}$ & $\begin{array}{r}0 . \\
4 \\
\end{array}$ & $\begin{array}{r}0 . \\
4\end{array}$ & $\begin{array}{r}0 . \\
6 \\
\end{array}$ & $\begin{array}{r}0 . \\
4 \\
\end{array}$ & 0.4 \\
\hline G23 & & $\begin{array}{r}0 . \\
4 \\
\end{array}$ & & & & & & & & \\
\hline G24 & & & & & & & & & & \\
\hline G25 & & & & & & & & & & \\
\hline
\end{tabular}




\begin{tabular}{|c|c|c|c|c|c|c|c|c|c|c|}
\hline G26 & & $\begin{array}{r}0 . \\
4\end{array}$ & & & $\begin{array}{r}0 . \\
4\end{array}$ & $\begin{array}{r}0 . \\
4\end{array}$ & $\begin{array}{r}0 . \\
4\end{array}$ & $\begin{array}{r}0 . \\
6\end{array}$ & & 0.6 \\
\hline G27 & & & & & $\begin{array}{r}0 . \\
4\end{array}$ & & $\begin{array}{r}0 . \\
4\end{array}$ & $\begin{array}{r}0 . \\
6\end{array}$ & & \\
\hline G28 & $\begin{array}{r}0 . \\
4\end{array}$ & $\begin{array}{r}0 . \\
4\end{array}$ & & $\begin{array}{r}0 . \\
4\end{array}$ & $\begin{array}{r}0 . \\
4\end{array}$ & $\begin{array}{r}0 . \\
4\end{array}$ & $\begin{array}{r}0 . \\
4\end{array}$ & $\begin{array}{r}0 . \\
4\end{array}$ & & 0.6 \\
\hline G29 & $\begin{array}{r}0 . \\
4\end{array}$ & & & & $\begin{array}{r}0 . \\
4\end{array}$ & $\begin{array}{r}0 . \\
4\end{array}$ & $\begin{array}{r}0 . \\
4\end{array}$ & $\begin{array}{r}0 . \\
6\end{array}$ & & 0.4 \\
\hline G30 & & & & & & & & & & \\
\hline G31 & $\begin{array}{r}0 . \\
4\end{array}$ & $\begin{array}{r}0 . \\
4\end{array}$ & $\begin{array}{r}0 . \\
4\end{array}$ & $\begin{array}{r}0 . \\
4\end{array}$ & $\begin{array}{r}0 . \\
4\end{array}$ & $\begin{array}{r}0 . \\
4\end{array}$ & $\begin{array}{r}0 . \\
4\end{array}$ & $\begin{array}{r}0 . \\
6\end{array}$ & $\begin{array}{r}0 . \\
4\end{array}$ & 0.4 \\
\hline G32 & $\begin{array}{r}0 . \\
4\end{array}$ & $\begin{array}{r}0 . \\
4\end{array}$ & $\begin{array}{r}0 . \\
4\end{array}$ & $\begin{array}{r}0 . \\
4\end{array}$ & $\begin{array}{r}0 . \\
4\end{array}$ & $\begin{array}{r}0 . \\
4\end{array}$ & $\begin{array}{r}0 . \\
4\end{array}$ & $\begin{array}{r}0 . \\
6\end{array}$ & $\begin{array}{r}0 . \\
4\end{array}$ & 0.4 \\
\hline G33 & $\begin{array}{r}0 . \\
4\end{array}$ & $\begin{array}{r}0 . \\
4\end{array}$ & $\begin{array}{r}0 . \\
4\end{array}$ & $\begin{array}{r}0 . \\
4\end{array}$ & $\begin{array}{r}0 . \\
4\end{array}$ & $\begin{array}{r}0 . \\
4\end{array}$ & $\begin{array}{r}0 . \\
4\end{array}$ & $\begin{array}{r}0 . \\
6\end{array}$ & $\begin{array}{r}0 . \\
4\end{array}$ & 0.4 \\
\hline G34 & $\begin{array}{r}0 . \\
6\end{array}$ & & $\begin{array}{r}0 . \\
6\end{array}$ & $\begin{array}{r}0 . \\
6\end{array}$ & & & & & $\begin{array}{r}0 . \\
4\end{array}$ & \\
\hline G35 & & $\begin{array}{r}0 . \\
4\end{array}$ & & & $\begin{array}{r}0 . \\
4\end{array}$ & $\begin{array}{r}0 . \\
4\end{array}$ & $\begin{array}{r}0 . \\
4\end{array}$ & $\begin{array}{r}0 . \\
6\end{array}$ & $\begin{array}{r}0 . \\
4\end{array}$ & 0.4 \\
\hline G36 & $\begin{array}{r}0 . \\
6\end{array}$ & & $\begin{array}{r}0 . \\
6\end{array}$ & $\begin{array}{r}0 . \\
6\end{array}$ & & & & & & \\
\hline G37 & & & & & $\begin{array}{r}0 . \\
2\end{array}$ & & & & & 0.8 \\
\hline
\end{tabular}

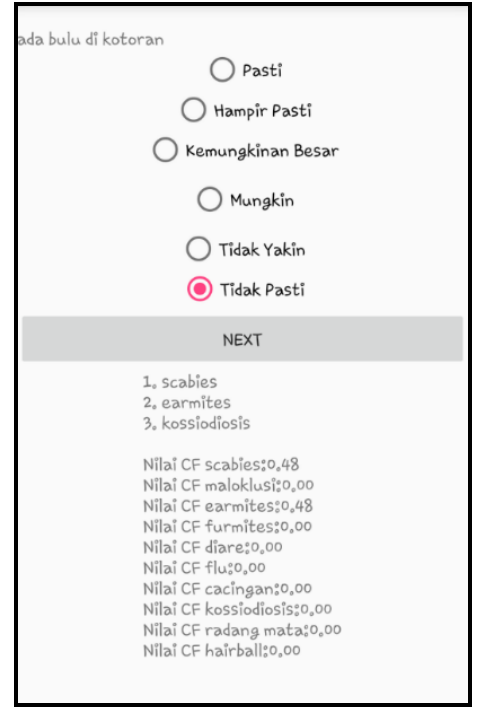

fig 3. Consultation result

\subsection{Mobile application implementation}

This section will show about screen captured of mobile application rabbit disease expert system. Figure 1 is user interface for user registration. Figure 2 shows how user input the symptoms of the disease. Figure 3 shows the result of the disease.

\begin{tabular}{|l|}
\hline \multicolumn{2}{c|}{ Form Register } \\
\hline Nama \\
\hline Alamat \\
Telepon \\
Email \\
Username \\
Password \\
\hline \\
\\
\\
\end{tabular}

fig 1. User Registration

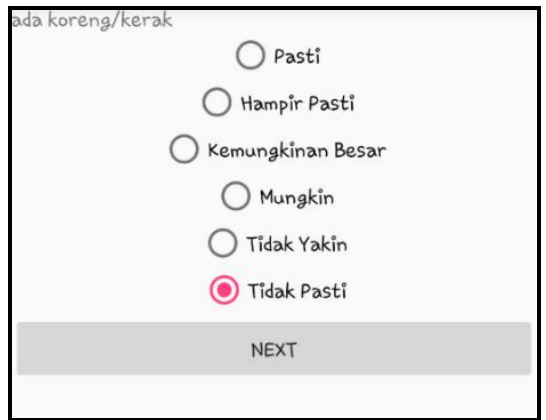

fig 2. Symptoms data input by use

\section{Result and Discussion}

System testing is testing the methods used in this system. Tests were carried out using inputted 15 sample data with symptoms. It ranges from 1 to 8 symptoms and disease. Table 4.1 shows the testing data to test the system.

Table 4.1 testing data

\begin{tabular}{|l|l|c|}
\hline No & \multicolumn{1}{|c|}{ Symptoms } & Disease \\
\hline 1 & G1, G2, G3, G6, G7 & furmites \\
\hline 2 & G1, G3 & scabies \\
\hline 3 & G13, G14 & malocclusion \\
\hline 4 & G11, G12 & flu \\
\hline 5 & G8, G9, G26, G27, G33 & diarrhea \\
\hline 6 & G3, G8, G9, G25, G26 & diarrhea \\
\hline 7 & G8, G9, G16, G17, G26, G29 & Hairball \\
\hline 8 & G37 & flu \\
\hline 9 & G11, G12 & Hairball \\
\hline 10 & G19, G20, G21 & coccidiosis \\
\hline 11 & G28, G29, G37 & scabies \\
\hline 12 & G8, G9, G19, G22, G32 & furmites \\
\hline 13 & G1 & earmites \\
\hline 14 & G2, G3, G6, G7 & inflammation \\
\hline 15 & G2, G4, G5, G9 & exps- \\
\hline
\end{tabular}

Testing of 15 testing data with 65 learning data in the expert system of diagnosing disease in rabbits and compared with the results of experts with the Naïve Bayes method. 65 learning data used to test 15 testing data, comparison of system tests with the expert have the following results:

a. There are 8 data from 15 sample data that match : $8 / 15 \times 100 \%=53 \%$

b. there are 7 data from 15 sample data does not match : $7 / 15 \times 100 \%=47 \%$

Testing of 15 testing data with 160 learning data in the expert system of diagnosing diseases in rabbits and compared with the results in experts with naïve Bayes method. 160 learning data used to test 15 testing data, comparison of system tests with the expert have the following results:

a. There are 11 data from 15 sample data that match : $11 / 15 \times 100 \%=73 \%$

b. there are 4 data from 15 sample data does not match : $4 / 15 \times 100 \%=27 \%$

\section{Testing with $\mathbf{C F}$}

Tests are carried out using 15 testing data with inputted symptoms ranging from 1-8 symptoms with variative $\mathrm{CF}$ values from user, used only to compare the results of user and expert trust. With 15 testing data comparison system tests with experts have the following results: 
a. there are 8 data from 15 sample data that match :

$8 / 15 \times 100 \%=53 \%$

b. there are 2 data from 15 sample data does not match : $2 / 15 \times 100 \%=13 \%$

c. there are 6 data from 15 sample data does not match : $5 / 15 \times 100 \%=33 \%$

Tests are carried out using 15 testing data with inputted symptoms ranging from 1-8 symptoms with certain $\mathrm{CF}$ values (1), used only to compare the results of user and expert trust. With 15 testing data comparison system tests with experts have the following results:

a. there are 8 data from 15 sample data that match :

$8 / 15 \times 100 \%=53 \%$

b. there are 1 data from 15 sample data does not match :

$1 / 15 \times 100 \%=7 \%$

c. there are 6 data from 15 sample data does not match : $6 / 15 \times 100 \%=40 \%$

\section{Conclusion}

From the results of design and development until the testing of the expert systems development programs for disease diagnosis in rabbits based on Android, conclusions obtained for further program development: from 15 sample data tested with Naïve Bayes method from 65 learning data compare with 160 learning data, the data produce different results, because the machine learns better.

The more learning data, the results will be more accurate. And from the 15 sample data tested by the certainty factor method, the $\mathrm{CF}$ value of the user combined with the expert $\mathrm{CF}$ value $=1 \mathrm{com}$ pared to the data tested with the variative $\mathrm{CF}$ user value, resulting in different results due to differences in values affecting the overall $\mathrm{CF}$ value.

\section{Acknowledgement}

The authors would like to thank to the Indonesian Directorate Gen-eral of the Higher Education (DIKTI) and State Polytechnic of Malang who have support this research project.

\section{References}

[1] Arsawijaya, Primaniartha (2016), Implementasi Metode Naïve Bayes Pada Sistem Pakar Diagnosa Gangguan Sistem Pernapasan Pada Anak. Semarang.

[2] Burhani, Ananda Ayu Zahara (2014), Sistem Pakar Diagnosis Penyakit Pada Kelinci Menggunakan Metode Certainty Factor, Jurnal Informatika Polinema, Volume:1, Edisi:1. November 2014

[3] Global-digital-report (2018), We Are Social, https://wearesocial.com/blog/2018/01/global-digital-report-2018

[4] Muhamad, Kanda Y. Kusumaningtyas, Pratiwi (2013), "Hewan Kesayangan" Penebar Swadaya. Jakarta

[5] Natalius, Samuel (2011), Metoda Naïve Bayes Classifier dan Penggunaannya pada Klasifikasi Dokumen, Institut Teknologi Bandung

[6] Sari, Hefti Budiana (2016), Sistem Pakar Diagnosa Penyakit Pada Kelinci Dengan Metode Forward Chaining. Yogyakarta.

[7] Syaifudin, Yan Watequlis., Pengembangan Sistem Paka Pengenalan Kepribadian Diri dengan Pendekatan Teori Myersbriggs Type Indicator. Proceeding SENDI_U, 2016

[8] Syatibi, Mustafid, Satoto (2012), Sistem Pakar Diagnosa Awal Penyakit Kulit Sapi Berbasis Web dengan Menggunakan Metode Certainty Factor. Masters Thesis, Diponegoro University.

[9] Wijaya, K.K. (2015), Berapa jumlah pengguna website, mobile, dan media sosial di Indonesia? dari http://id.techinasia.com/ 